\title{
THE AVAILABILITY TO ALFALFA OF PHOSPHORUS FROM TWELVE DIFFERENT GARRIERS ${ }^{1}$
}

\author{
J. D. BEATON ${ }^{2}$ AND K. F. NIELSEN ${ }^{3}$ \\ Canada Department of Agriculture
}

[Received for publication November 21, 1958]

\begin{abstract}
Availabilities of the phosphorus in twelve different phosphate sources to alfalfa were determined in a growth chamber. Two crops of alfalfa were grown on two soils of high base status, Machete stony sandy loam and Westwold loam. Fertilizer materials containing monocalcium phosphate or materials such as calcium metaphosphate which are converted to monocalcium phosphate brought about the greatest increases in yield. However, yield increases also resulted from treatments with the ammonium phosphates and orthophosphoric acid. Ammonium phosphate fertilizers were the most effective in increasing the percentage of phosphorus present in the alfalfa tissue. Ammonium phosphate and monocalcium phosphate materials were equally effective in increasing total phosphorus uptake by alfalfa. The amount of $\mathrm{CO}_{2}$ soluble phosphorus extracted from the Westwold loam, following treatment with the various phosphate sources, was correlated with the yield of the first crop of alfalfa. The average per cent $P$ in the alfalfa tissue was found to be correlated with the $\mathrm{CO}_{2}$ soluble $\mathrm{P}$. Both the $\mathrm{NaHCO}_{3}$ and $\mathrm{CO}_{2}$ extractable soil phosphorus levels of the Westwold loam, after it had been treated with the different phosphate materials, were found to be highly correlated with the phosphorus uptake by the second crop of alfalfa and with the total phosphorus uptake.
\end{abstract}

\section{INTRODUGTION}

Phosphate fertilizers are frequently used to increase the yields of alfalfa grown on interior British Columbia soils. It has been pointed out by Beaton (1) that the effectiveness of the different sources, on alfalfa being grown on soils of high base status in British Columbia, varied considerably. In this study an attempt was made to evaluate the availability of phosphorus in a number of carriers to alfalfa being grown on two soils of high base status.

A number of workers have investigated the efficiency of phosphate fertilizers on several crops. Mitchell $(8,9)$ reported that monoammonium phosphate was superior to mono- and dicalcium phosphate in the utilization of phosphorus by grain crops grown in Saskatchewan. Similarly, Dion et al. (4) found that the relative efficiency of monoammonium, monocalcium and tricalcium phosphate, as phosphate sources for wheat, decreased in that order. It was shown by Owens et al. (13) that the phosphorus content of sugar beet plants fertilized with a high water soluble phosphate was significantly higher than for plants fertilized with a low water soluble phosphate. No differences were found, however, in the final yields of beets. In a comparison of calcium metaphosphate with concentrated superphosphate Terman and Seatz (17) found that calcium metaphosphate was, in general, a satisfactory source of phosphorus for alfalfa and other hay crops grown on calcareous soils while it was poorer than concentrated

1 Contribution from the Field Husbandry Divisions of the Range Experimental Farm, Kamloops, B.C., and the Central Experimental Farm, Ottawa, Ont.

2 Formerly Soil Specialist, Range Experimental Farm, Kamloops, B.C.; present address, Department of

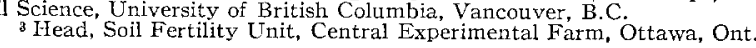


superphosphate for potatoes, sugar-beets and spring-sown small grain. The best source of phosphorus for ryegrass and Sudangrass on calcareous soils was observed by Terman et al. (19) to be monocalcium phosphate. Terman et al. (18) reported that early growth response, as determined in the greenhouse with oats and Sudangrass, and in the field with wheat forage and other crops, increased with smaller granule sizes of the low water-soluble fertilizers but decreased with smaller granule sizes of the high water-soluble fertilizers.

\section{MATERIALS AND METHODS}

Surface samples ( 0 to 6 inches) of two soils high in base status, the Machete stony sandy loam and the Westwold loam, were air-dried and sieved through a 10-mesh sieve. Some characteristics of the two soils are listed in Table 1.

Ten pounds of soil were placed in one-gallon glazed porcelain crocks. To reduce the influence of granule size, all the phosphate sources, with the exception of $\mathrm{H}_{3} \mathrm{PO}_{4}$, were ground to pass a 100 -mesh sieve. These materials were thoroughly mixed with each aliquot of soil before the soil was added to the crocks. One level of phosphate, 120 pounds of $\mathrm{P}_{2} \mathrm{O}_{5}$ per 2 million pounds of soil, was provided by the materials listed in Table 2 . The phosphorus content of the commercial fertilizers and hydroxyapatite was determined by the method of Shelton and Harper (16). The hydroxyapatite was prepared in the laboratory according to the procedure outlined by Egan et al. (6). Since several of the phosphate fertilizers contained nitrogen, ammonium nitrate in solution was added to the pots to establish a uniform rate of 96 pounds of $\mathrm{N}$ per 2 million pounds of soil for each treatment. The treatments were replicated four times and were randomized for each soil.

Tensiometers were used to indicate soil moisture tension in the crocks. Immediately following the installation of the tensiometers the soil was moistened and maintained at approximately 0.2 atm. for a period of 3 weeks. After this period, as well as at the end of the experiment, small samples of soil were taken from each crock. Total phosphorus, carbonic acid and $\mathrm{NaHCO}_{3}$ extractable phosphorus were determined on these samples. Ten germinated Grimm alfalfa seeds, which had been inoculated, were then placed in each crock. The plants were later thinned to leave a total of five. When the soil moisture tension reached $0.8 \mathrm{~atm}$., sufficient water was added to lower it to $0.2 \mathrm{~atm}$.

The crocks were placed in a growth chamber at Kamloops, where the radiant energy was supplied by a light assembly consisting of cool white fluorescent tubes and red incandescent bulbs. To provide a light intensity of 1000 foot candles at the top of the alfalfa plants, the light assembly was maintained at a height of about 8 inches above the plants. Alternating periods of 16 hours of light and 8 hours of darkness were maintained throughout the duration of the experiment. While the lights were on, the temperature remained at about $80^{\circ} \mathrm{F}$; when they were off it was about $60^{\circ} \mathrm{F}$. Two crops of alfalfa were harvested, the first 6 weeks following planting, and the second approximately 4 weeks after the first harvest.

The tissue was then dried at $70^{\circ} \mathrm{C}$, weighed, ground in a Wiley Mill and stored for analysis. 


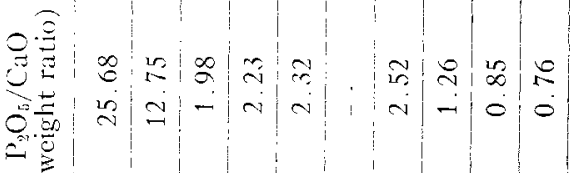

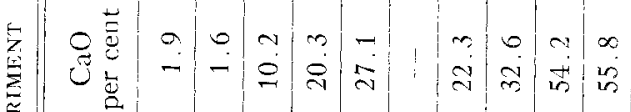

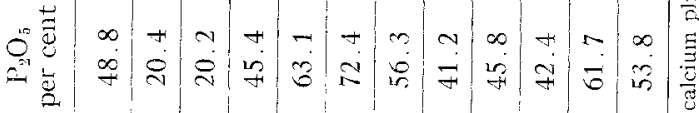

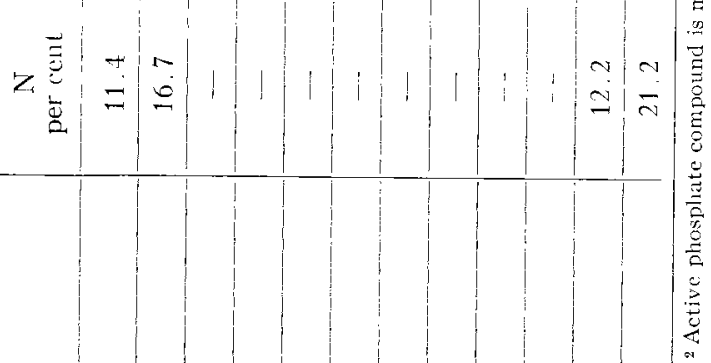

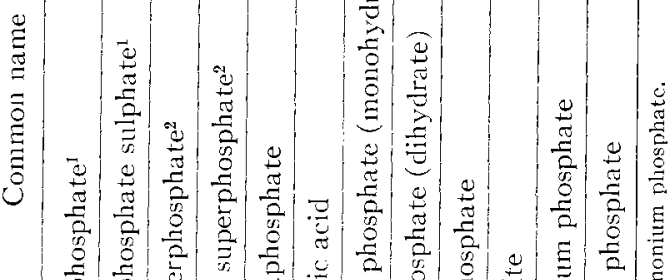

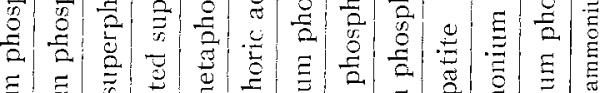

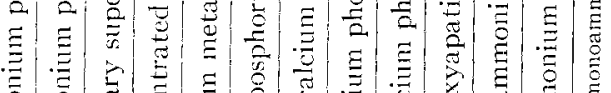

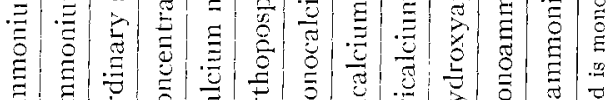
寻

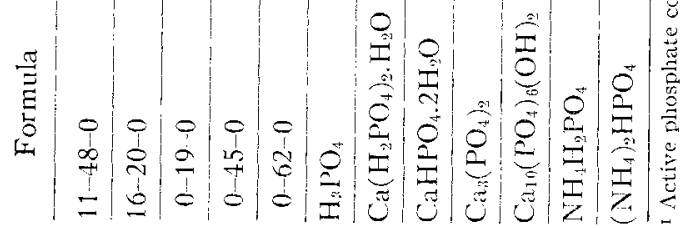


Cation exchange capacity, exchangeable cations and conductivity of the soil-saturation extract were determined according to the methods outlined by the U. S. Salinity Laboratory (21). Soil $\mathrm{pH}$ was determined on the soil paste as advocated by Doughty (5). The organic matter determinations were made by the method described by Peech et al. (14). Total phosphorus in the soil and plant samples was determined by the procedure of Shelton and Harper (16). The carbonic acid extraction of soil phosphorus was a modification of the $\mathrm{CO}_{2}$ extraction procedure used by Wilcox* and the technique advocated by the National Soil and Fertilizer Research Committee (10). The $\mathrm{NaHCO}_{3}$ extractable phosphorus was determined by the procedure of Olsen et al. (12). Percentages of sand, silt and clay were determined by the Bouyoucos hydrometer method (2).

\section{RESULTS AND DISGUSSION}

Yields of alfalfa forage are summarized in Table 3 . In the case of the first cut, treatment with 11-48-0, 16-20-0, 0-19-0, 0-45-0, 0-62-0 and $\mathrm{H}_{3} \mathrm{PO}_{4}$ on the Machete stony sandy loam all gave yields significantly larger than that of the no phosphorous treatment. The 0-62-0 treatment gave a significantly higher yield than any of the other phosphate sources. With the exception of the 0-62-0 treatment, $0-45-0$ gave a significantly greater yield than the other phosphorus supplements. The response of alfalfa to 0-62-0 in the first cut is somewhat surprising since the data of Hignett** indicated that calcium metaphosphate dissolved slowly in water with the formation of soluble nonorthophosphates which gradually hydrolyzed to orthophosphates. Tisdale and Nelson (20) stated that calcium meta-

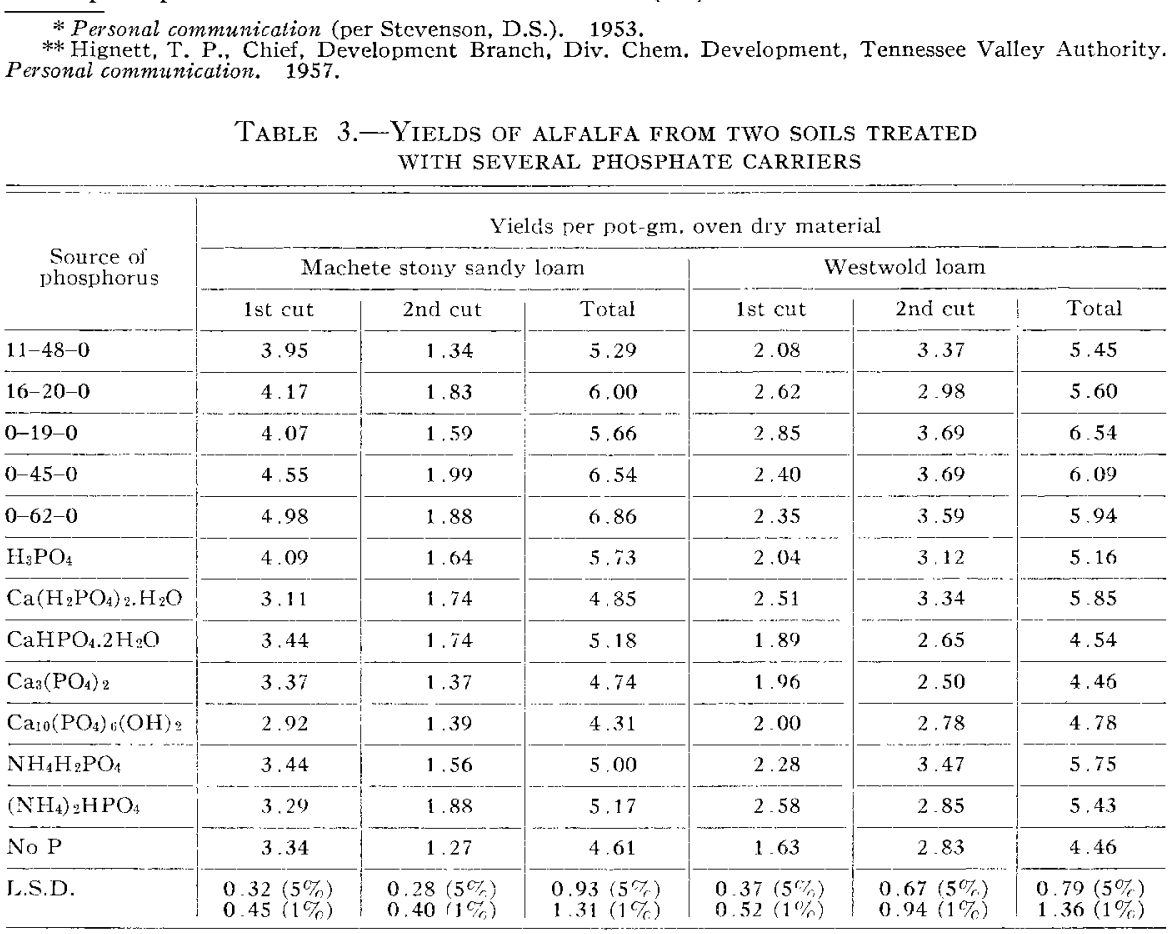


phosphate generally reacts too slowly in alkaline soils to show much response in the first year. They indicated, however, that more favourable results have been obtained with it on calcareous soils than with di- or tricalcium phosphates. Newman and Hill (11) concluded that, although calcium metaphosphate is classed by conventional fertilizer criteria as a waterinsoluble phosphate, the quality of its insolubility is different from that of the common insoluble phosphates because it can absorb water slowly and change to soluble monocalcium phosphate.

Significant increases in yield above that of the check were obtained in the second harvest by the treatments with 16-20-0, 0-19-0, 0-45-0, 0-62-0, $\mathrm{H}_{3} \mathrm{PO}_{4}, \mathrm{Ca}\left(\mathrm{H}_{2} \mathrm{PO}_{4}\right)_{2} . \mathrm{H}_{2} \mathrm{O}, \mathrm{CaHPO}_{4} .2 \mathrm{H}_{2} \mathrm{O}, \mathrm{NH}_{4} \mathrm{H}_{2} \mathrm{PO}_{4}$ and $\left(\mathrm{NH}_{4}\right)_{2} \mathrm{HPO}_{4}$. Concentrated superphosphate gave significantly higher results than all the above treatments with the exception of 0-62-0 and $\left(\mathrm{NH}_{4}\right)_{2} \mathrm{HPO}_{4}$. Both 0-62-0 and $\left(\mathrm{NH}_{4}\right)_{2} \mathrm{HPO}_{4}$ gave significantly higher yields than 0-19-0 and $\mathrm{NH}_{4} \mathrm{H}_{2} \mathrm{PO}_{4}$. Applications of $\mathrm{Ca}_{3}\left(\mathrm{PO}_{4}\right)_{2}, \mathrm{Ca}_{10}\left(\mathrm{PO}_{4}\right)_{6}(\mathrm{OH})_{2}$ and 11-48-0 did not bring about increases in yield. The observation that $0-62-0$ and $0-45-0$ treatments resulted in comparable yields of alfalfa is in accordance with the findings of Terman and Seatz (17) as well as other earlier workers. The total yield was found to be significantly increased by the addition of $16-20-0,0-19-0$, 0-45-0, 0-62-0 and $\mathrm{H}_{3} \mathrm{PO}_{4}$. Of these treatments only 0-62-0 was significantly greater than $\mathrm{H}_{3} \mathrm{PO}_{4}$.

With respect to the Westwold loam, 11-48-0, 16-20-0, 0-19-0, 0-45-0, 0-62-0, $\mathrm{H}_{3} \mathrm{PO}_{4}, \mathrm{Ca}\left(\mathrm{H}_{2} \mathrm{PO}_{4}\right)_{2} \cdot \mathrm{H}_{2} \mathrm{O}, \mathrm{NH}_{4} \mathrm{H}_{2} \mathrm{PO}_{4}$ and $\left(\mathrm{NH}_{4}\right)_{2} \mathrm{HPO}_{4}$ all gave significant increases in the yield of the first cut. The $0-19-0$ source gave the highest yield and significantly outyielded $11-48-0,0-45-0,0-62-0$, $\mathrm{H}_{3} \mathrm{PO}_{4}$ and $\mathrm{NH}_{4} \mathrm{H}_{2} \mathrm{PO}_{4}$. It was also found that 16-20-0 caused significantly larger yields than 11-48-0 and $\mathrm{H}_{3} \mathrm{PO}_{4}$. Once again $\mathrm{CaHPO}_{4}$ . $2 \mathrm{H}_{2} \mathrm{O}, \mathrm{Ca}_{3}\left(\mathrm{PO}_{4}\right)_{2}$ and $\mathrm{Ca}_{10}\left(\mathrm{PO}_{4}\right)_{6}(\mathrm{OH})_{2}$ did not appreciably affect the yields of alfalfa. There is some evidence of a response to sulphur as well as phosphorus on the Westwold loam. Both $0-19-0$ and 16-20-0, which contained 36.4 and 45.8 per cent $\mathrm{SO}_{4}^{-}$, respectively, brought about larger increases in yield than their respective counterparts, $0-45-0$ and 11-48-0 which contained considerably less sulphur. This sulphur response appears to have occurred only in the early stages of plant growth since a similar response was not observed in the second harvest. Only $0-19-0,0-45-0$ and 0-62-0 treatments resulted in increased yields of the second harvest of alfalfa from the Westwold loam. The total yield of the 11-48-0, 16-20-0, 0-19-0, 0-45-0, 0-62-0, $\mathrm{Ca}\left(\mathrm{H}_{2} \mathrm{PO}_{4}\right) \cdot \mathrm{H}_{2} \mathrm{O}, \mathrm{NH}_{4} \mathrm{H}_{2} \mathrm{PO}_{4}$, and $\left(\mathrm{NH}_{4}\right)_{2} \mathrm{HPO}_{4}$ treatments was found to be significantly greater than that of the check. Of these treatments, $11-48-0,16-20-0$ and $\left(\mathrm{NH}_{4}\right)_{2} \mathrm{HPO}_{4}$ gave total yields that were less than that of the $0-19-0$ treatment.

It is evident that for both soils and for both harvests the monocalcium phosphate form and materials, such as calcium metaphosphate, which are gradually converted to monocalcium phosphate, were more effective than the dicalcium phosphate form. On the Machete stony sandy loam however, the $\mathrm{Ca}\left(\mathrm{H}_{2} \mathrm{PO}_{4}\right)_{2} \cdot \mathrm{H}_{2} \mathrm{O}$ treatment was generally not effective, even though other materials such as $0-19-0$ and $0-45-0$, which contain this form 
of phosphate, were effective. There appears to be no satisfactory explanation for this discrepancy. Lehr and Brown (7) suggested that the superiority of monocalcium phosphate over dicalcium phosphate dihydrate was related to the greater specific surface and wider distribution of the phosphate formed from monocalcium phosphate. The greater response to monocalcium phosphate was also believed to be related to phosphate made available during hydrolysis of dicalcium phosphate dihydrate to octaphosphate, which was found to be greater in the monocalcium phosphate treatment. The hydrolytic reactions were pictured as follows:

$$
\mathrm{Ca}\left(\mathrm{H}_{2} \mathrm{PO}_{4}\right)_{2} \cdot \mathrm{H}_{2} \mathrm{O} \longrightarrow \mathrm{CaHPO}_{4} \cdot 2 \mathrm{H}_{2} \mathrm{O} \longrightarrow \mathrm{CaHPO}_{4} \text {. }
$$

The hydrolysis of dicalcium phosphate dihydrate, which is formed by hydrolysis from monocalcium phosphate, was believed to enhance the availability of part of the phosphorus to the plant in either of two ways:

1. $4 \mathrm{CaHPO}_{4} \cdot 2 \mathrm{H}_{2} \mathrm{O} \longrightarrow \mathrm{Ca}_{4} \mathrm{H}\left(\mathrm{PO}_{4}\right)_{3} \cdot 3 \mathrm{H}_{2} \mathrm{O}+\mathrm{H}_{3} \mathrm{PO}_{4}+5 \mathrm{H}_{2} \mathrm{O} .\left(\mathrm{H}_{3} \mathrm{PO}_{4}\right.$ may be readily available).

2. If the concentration of $P$ in the fertilizer zone is governed by the solubility product of dicalcium phosphate, the removal of excess $\mathrm{Ca}^{++}$ions by precipitation of the octocalcium phosphate would permit a higher concentration of phosphate to exist. Lehr and Brown also pointed out that in alkaline soils the presence of plants tended to bring about even greater hydrolysis of monocalcium phosphate with the formation of octaphosphate. Presumably, the plant roots absorbed phosphate leaving the excess $\mathrm{Ca}^{++}$ions to be precipitated as octaphosphate or apatite.

The greater effectiveness of monocalcium phosphate over dicalcium phosphate dihydrate in such soils may also be explained by the existence of soil solutions supersaturated with respect to dicalcium phosphate. Clark and Turner (3) recognized, in a study of reactions between solid calcium carbonate and orthophosphate solutions, the presence of solutions that were supersaturated with respect to dicalcium phosphate. If such supersaturated solutions existed in soils of high base status, it is possible that growing plants could readily utilize the temporary excess of phosphate in solution.

The ammonium phosphate fertilizers also brought about increases in the yield of alfalfa from both soils. However, these increases in yield were not as large as those resulting from the monocalcium phosphate treatments. This observation is in accordance with the suggestion by Beaton (1) that the ammonium phosphate bearing fertilizers, such as 1148-0 and 16-20-0, were not as effective as the monocalcium fertilizers for perennial crops, such as alfalfa, being grown on soils of high base status. In view of the work reported by Clark and Turner (3), where hydroxyapatite was shown to be the thermodynamically stable form of phosphate in calcareous and alkaline soils, and because its rate of formation will be dependent on the concentration of phosphate, particularly $\mathrm{PO}_{\overline{4}}^{\overline{4}}$, in solution, it was believed by Beaton that the highly soluble ammonium phosphate provided adequate phosphate for the ready precipitation of hydroxyapatite. If the formation of hydroxyapatite was favoured, the amount of phosphate in the soil solution available for plant grow th would be considerably decreased, whereas the monocalcium phosphate materials would be converted to dicalcium phosphate and eventually to octaphosphate and 


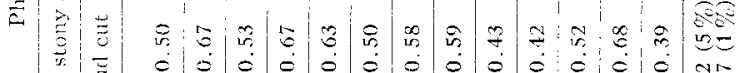

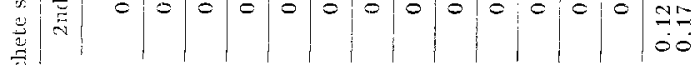

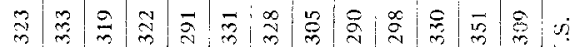

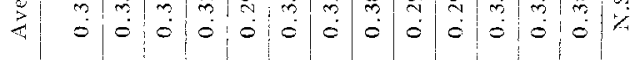

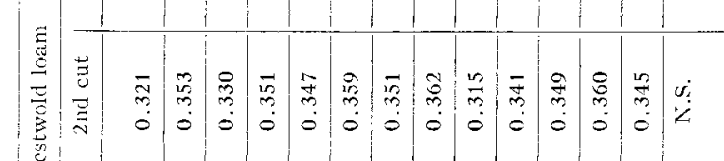

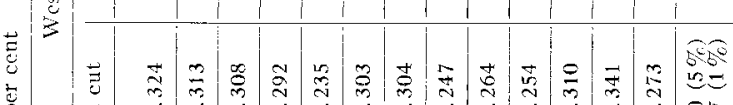

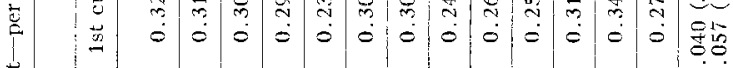


hydroxyapatite. With such a conversion there probably would be sufficient phosphate in solution for plant growth but not enough to permit the rapid formation of hydroxyapatite.

The per cent phosphorus present in the alfalfa tissue is given in Table 4. With the Machete stony sandy loam the 11-48-0, 16-20-0, 0-19-0 and $\mathrm{H}_{3} \mathrm{PO}_{4}$ treatments resulted in significant increases in the first cut. The per cent $\mathrm{P}$ value with the 16-20-0 treatment was significantly larger than with the $\mathrm{H}_{3} \mathrm{PO}_{4}$ treatment. In the second cut and in the average phosphorus content only the 11-48-0, 16-20-0 and $\left(\mathrm{NH}_{4}\right)_{2} \mathrm{HPO}_{4}$ treatments brought about significant increases in the percentage of phosphorus present in the alfalfa tissue. The results obtained from the alfalfa grown on the Westwold loam were significant for the first harvest only. Three treatments, 11-48-0, 16-20-0 and $\left(\mathrm{NH}_{4}\right)_{2} \mathrm{HPO}_{4}$, were found to give significantly higher values than the check.

From the above results it appears that ammonium phosphate fertilizers were the most effective in raising the phosphorus content of alfalfa. This observation is in agreement with the results obtained by Owens et al. (13), where it was found that the phosphorus content of sugar beets was higher with a high water soluble fertilizer than with a low water soluble fertilizer. The increase in percent $\mathrm{P}$ in the alfalfa tissue may be the result of the presence of the $\mathrm{NH}_{4}^{+}$ion. Rennie and Soper (15) reported that $\mathrm{NH}_{4}{ }^{+}$ had a stimulative effect on phosphorus uptake by wheat during the early stages of growth. It was found also that placement was important, as increased phosphorus uptake occurred only when the ammonium ion was intimately associated with the fertilizer phosphorus.

This stimulative effect may partially explain the response of alfalfa to the ammonium phosphate fertilizers. If the $\mathrm{NH}_{4}{ }^{+}$ion does enhance phosphorus uptake and if optimum levels of $\mathrm{NH}_{4}{ }^{+}$ion do not exist, diammonium phosphate may prove to be more effective than monoammonium phosphate since it has more ammonium per unit concentration of phosphate.

The high phosphorus content of alfalfa that resulted from treatment with the ammonium phosphate fertilizer materials may also have been due to the initial high water solubility of these materials which would have permitted rapid absorption by plants. Later, upon conversion of the soluble phosphate to hydroxyapatite, as postulated previously, a reduction in plant uptake and plant growth would probably occur. Any subsequent growth with less phosphorus being absorbed would thus tend to dilute the initial high phosphorus content to the values observed.

The results of phosphorus uptake, which are also recorded in Table 4 , show that the additions of $11-48-0,16-20-0,0-19-0,0-45-0,0-62-0$ and $\mathrm{H}_{3} \mathrm{PO}_{4}$ were responsible for significant increases over the check with the first crop and with the total phosphorus uptake by alfalfa grown on the Machete stony sandy loam. The 0-62-0 treatment was found to result in significantly more total phosphorus uptake than the 11-48-0 and $\mathrm{H}_{3} \mathrm{PO}_{4}$ treatments. Significant increases in the phosphorus uptake by the second cut were obtained with 16-20-0, 0-19-0, 0-45-0, 0-62-0, $\mathrm{Ca}\left(\mathrm{H}_{2} \mathrm{PO}_{4}\right)_{2} \cdot \mathrm{H}_{2} \mathrm{O}$, $\mathrm{CaHPO}_{4} .2 \mathrm{H}_{2} \mathrm{O}, \mathrm{NH}_{4} \mathrm{H}_{2} \mathrm{PO}_{4}$ and $\left(\mathrm{NH}_{4}\right)_{2} \mathrm{HPO}_{4}$. The phosphorus uptake in the first harvest of alfalfa and the total $\mathrm{P}$ uptake from the Westwold loam 
was increased significantly by the 11-48-0, 16-20-0, 0-19-0,0-45-C, 0-62-0, $\mathrm{H}_{3} \mathrm{PO}_{4}, \mathrm{Ca}\left(\mathrm{H}_{2} \mathrm{PO}_{4}\right)_{2} . \mathrm{H}_{2} \mathrm{O}, \mathrm{NH}_{4} \mathrm{H}_{2} \mathrm{PO}_{4}$ and $\left(\mathrm{NH}_{4}\right)_{2} \mathrm{HPO}_{4}$ treatments. In the first harvest the values for 16-20-0, 0-19-0, and $\left(\mathrm{NH}_{4}\right)_{2} \mathrm{HPO}_{4}$ were significantly greater than for the rest. Significantly more total phosphorus uptake occurred with the 0-19-0 treatment than with the 11-48-0 and $\mathrm{H}_{3} \mathrm{PO} 4$ treatments. Phosphorus uptake by the second harvest of alfalfa from the Westwold loam was significantly increased by $0-19-0,0-45-0,0-62-0$ and $\mathrm{NH}_{4} \mathrm{H}_{2} \mathrm{PO}_{4}$.

The correlation coefficients (r) were calculated relating $\mathrm{NaHCO}_{3}$ and $\mathrm{H}_{2} \mathrm{CO}_{3}$ extractable soil phosphorus to yield, per cent phosphorus in tissue and phosphorus uptake by alfalfa grown on the Westwold loam. There was no correlation between $\mathrm{NaHCO}_{3}$ extraction and yield. The $\mathrm{CO}_{2}$ extraction was correlated $(r=0.58)$ with yields in the first cut but not with second cut. The average per cent $\mathrm{P}$ was found to be correlated $(r=0.56)$ with only $\mathrm{CO}_{2}$ soluble $\mathrm{P}$. Both the $\mathrm{NaHCO}_{3}(\mathrm{r}=0.89$ and 0.81$)$ and $\mathrm{CO}_{2}(\mathrm{r}=0.93$ and $\mathrm{r}=0.60)$ extractable soil phosphorus values were found to be highly correlated with phosphorus uptake by the second crop and with the total phosphorus uptake. Terman et al. (19) reported a significant correlation between the phosphorus extracted by $0.5 \mathrm{~N} \mathrm{NaHCO}_{3}$ and the phosphorus uptake by ryegrass and Sudangrass from six different phosphate sources.

\section{REFERENCES}

1. Beaton, J. D. Fertility problems encountered in forage crop production on B. C. Interior soils under irrigation and dryland farming. Report, B. C. Agronomists' Conference. 1957.

2. Bouyoucos, G. J. A recalibration of the hydrometer method for making mechanical analysis of soil. Amer. Soc. Agron. J. 43:434-437. 1951.

3. Clark, J. S., and R. C. Turner. Reactions between solid calcium carbonate and orthophosphate solutions. Can. J. Chem. 33:665-671. 1955.

4. Dion, H. G., J. W. T. Spinks, and J. Mitchell. Experiments with radiophosphorus on the uptake of phosphorus by wheat. Sci. Agr. 29:512-526. 1949.

5. Doughty, J. L. The advantage of a soil paste for routine $\mathrm{pH}$ determinations. Sci. Agr. 22:135-138. 1941.

6. Egan, Edward P., Jr., Zachary T. Wakefield, and Kelly L. Elmore. High temperature heat content of hydroxyapatite. J. Amer. Chem. Soc. 72:2418-2421. 1950.

7. Lehr, J. R., and W. E. Brown. Calcium phosphate fertilizers. II, A petrographic study of their alteration in soils. Soil Sci. Soc. Amer. Proc. 22:29-32. 1958.

8. Mitchell, J. The effects of phosphate fertilizers on summer fallow wheat crops in certain areas of Saskatchewan. Sci. Agr. 26:566-577. 1946.

9. Mitchell, J. A review of tracer studies in Saskatchewan on the utilization of phosphates by grain crops. J. Soil Sci. 8:73-85. 1957.

10. National Soil and Fertilizer Research Committee. Soil testing in the United States. 1951

11. Newman, E. L., and W. L. Hill. New and better fertilizers. U.S.D.A. Yearbook of Agriculture, pp. 210-216. Washington, D. C. 1957.

12. Oisen, S. R., C. V. Cole, F. Watanabe, and L. A. Dean. Estimation of available phosphorus in soils by extraction with sodium bicarbonate. U.S.D.A. Circ. 939. Washington, D. C. 1954.

13. Owens, L., K. Lawton, L. S. Robertson, and C. Apostolakis. Laboratory, greenhouse and field studies with mixed fertilizers varying in water-soluble phosphorus content and particle size. Soil Sci. Soc. Amer. Proc. 19:315-319. 1955.

14. Peech, M., L. T. Alexander, L. A. Dean, and J. F. Reed. Methods of soil analysis for soil fertility investigations. U.S.D.A. Circ. 757. Washington, D. C. 1947. 
15. Rennie, D. A., and R. J. Soper. The effect of nitrogen additions on fertilizer-phosphorus availability. II. J. Soil Sci. 9:155-167. 1958.

16. Shelton, W. R., and H. J. Harper. A rapid method for the determination of total phosphorus in soil and plant material. Iowa State Coll. J. Sci. 15:403-413. 1941.

17. Terman, G. L., and L. F. Seatz. Crop response to metaphosphate fertilizers. Soil Sci. Soc. Amer. Proc. 20:375-378. 1956.

18. Terman, G. L., J. L. Anthony, W. P. Mortensen, and J. A. Lutz, Jr. Crop response to NPK fertilizers varying in granule size and water solubility of phosphorus. Soil Sci. Soc. Amer. Proc. 20:551-556. 1956.

19. Terman, G. L., D. R. Bouldin, and J. R. Lehr. Calcium phosphate fertilizers. I. Availability to plants and solubility in soils varying in $\mathrm{pH}$. Soil Sci. Soc. Amer. Proc. 22:25-29. 1958.

20. Tisdale, Samuel L., and L. Nelson Werner. Soil fertility and fertilizers. MacMillan Co., New York, N. Y. 1956.

21. U. S. Salinity Laboratory Staff. Diagnosis and improvement of saline and alkali soils. U. S. D. A. Handbook 60. Washington, D.C. 1954. 